\title{
O DIREITO FUNDAMENTAL À MOTIVAÇÃO NO PROCESSO PENAL COMO COROLÁRIO DE OUTRAS GARANTIAS CONSTITUCIONAIS
}

\author{
FABRÍCIO DREYER DE AVILA POZZEBON*
}

\begin{abstract}
RESUMO: O presente estudo visa afirmar a motivação no processo penal brasileiro como direito fundamental a partir da abertura material autorizada pelo parágrafo $2^{\circ}$ do artigo $5^{\circ} \mathrm{da}$ Constituição Federal e como corolário de outras garantias constitucionais imanentes de modo a intensificar sua eficácia.

PALAVRAS-CHAVE: Direito Processual Penal, Garantias Constitucionais, Direito à Fundamentação, Eficácia Material.

ABSTRACT: The present study aims at affirming motivation in the Brazilian penal process as a fundamental right from the material opening authorized by paragraph 2 of Article 5 of the Federal Constitution and as a corollary of other immanent constitutional guaranties in order to increase its effectiveness.

KEYWORDS: Penal Procedural Law, Constitutional Guarantees, Right to Motivation, Material Efficacy.
\end{abstract}

SUMÁRIO: 1. Considerações iniciais. 2. O direito fundamental à motivação das decisões judiciais. 3. A motivação como corolário de outras garantias constitucionais. 3.1 Dignidade da pessoa humana. 3.2 Devido processo legal. 3.3 Contraditório e ampla defesa. 3.4 Presunção de inocência. 3.5 Duplo grau de jurisdição. 4. Conclusão. 5. Bibliografia.

SUMMARY: 1. Initial remarks. 2. The fundamental right to motivation of judicial decisions. 3. The motivation as a corollary of other constitutional guarantees. 3.1. Human person dignity. 3.2. Due process of law. 3.3. Contradiction and wide defense. 3.4. Presumption of innocence. 3.5. Dual degree of jurisdiction. 4. Conclusion. 5. Bibliography.

\section{CONSIDERAÇÕES INICIAIS}

A opção pelo caráter disciplinar ou interdisciplinar como caminho para a construção do discurso científico permanece como tema em discussão nos círculos epistemológicos, juntamente com a dimensão em que essa interdisciplinaridade se dá. Neste sentido, afirma Geraldo PRADO $^{1}$ que a dogmática processual penal crítica da

Artigo recebido em $1^{\circ} .05 .2009$ e aprovado para publicação pelo Conselho Editorial em 14.10.2009.

* Doutor em Direito (PUCRS) e Professor Titular da Faculdade de Direito da PUCRS.

${ }^{1}$ PRADO, Geraldo. Sistema acusatório. A conformidade constitucional das leis procesuais penais. 3. ed. Rio de Janeiro: Lumen Juris, 2005, p. 03. Para o autor, a análise jurídica dos fenômenos só obtém status de apreciação científica quando considera a relação inevitável entre o que se quer conhecer o funcionamento do Sistema da Justiça Penal - e quem quer conhecer. Não existe conhecimento objetivo e asséptico dos fenômenos da vida em sociedade. 
atualidade, ou seja, o conjunto de conceitos e categorias utilizados pelo jurista, é fruto do diálogo entre as diversas áreas do conhecimento, de forma que a malograda separação entre as disciplinas, que relegava a sociologia e a filosofia, por exemplo, a postos secundários na estrutura do aprendizado do Direito, a partir da suposição de que nada serviriam no futuro, ruiu.

O fenômeno social, hoje, na sua crescente complexidade, busca como objeto, incisões que lhe dêem o formato para que possa ser apreendido pelo espírito humano. Presente está, nesta atividade, a objetivação do sujeito e a subjetivação do objeto, de forma a negar o "fato puro", político, econômico, histórico ou jurídico. Ausentes as disciplinas não teremos interdisciplinaridade de modo que o próprio saber disciplinar avance na direção de outras áreas do conhecimento, visando à necessária complementaridade. Enfim, o disciplinar leva ao interdisciplinar e este último faz retornar ao primeiro. ${ }^{2}$

Importante para caracterizar a complexidade ${ }^{3}$ da sociedade atual e o final das certezas com que o juiz tem de lidar, dispõe Ruth GAUER ${ }^{4}$ que enquanto o conceito de "tempo" privilegiava, na ciência clássica, a ordem e a estabilidade, a "velocidade" cada vez mais acelerada, especialmente, no século XX, leva à instabilidade, à flutuação, a escolhas múltiplas, à imprevisibilidade. Ilya PRIGOGINE, Prêmio Nobel de Química, ao tratar do "paradoxo do tempo", identificado na segunda metade do século XIX, transporta para física o dilema: tempo x determinismo que, segundo o autor, "não se limita às ciências, estando no centro do pensamento ocidental desde a origem do que denominamos de racionalidade". Ao trabalhar com conceitos como "irreversibilidade" (a partir do momento em que foi lançada a "flecha do tempo"); de "instabilidade" e "imprevisibilidade” (ao contrário da ciência clássica que, como visto, privilegiava a ordem, a estabilidade, a previsibilidade e a certeza); “caos” (como noção que se tornou popular em todas as áreas de conhecimento, inclusive da cosmologia ao Direito).

Assim, a partir dessa realidade e do necessário diálogo entre as áreas do saber é possível identificar a tempestuosa crise enfrentada pelo conhecimento racional e seus reflexos no papel do juiz e da jurisdição o que leva à busca das garantias constitucionais como referência. A crítica à concepção tradicional sobre o efetivo

\footnotetext{
2 CARVAlHO, Paulo de Barros. Prefácio. In: CAMPILONGO, Celso Fernandes. Política, Sistema Jurídico e Decisão Judicial. São Paulo: Max Limonad, 2002. p. 7-8.

${ }^{3}$ Utiliza-se o termo como MORIN, Edgar. Introdução ao Pensamento Complexo, Lisboa, Instituto Piaget, 1991, p. 17/19: “complexidade é o tecido de acontecimentos, ações, interações, retroações, determinações, acasos, que constituem o nosso mundo fenomenal, apresentando-se com os traços inquietantes da confusão, do inextricável, da desordem, da ambigüidade, da incerteza, o que leva à necessidade, para o conhecimento, de pôr ordem nos fenômenos ao rejeitar a desordem, de afastar o incerto, isto é, de selecionar os elementos de ordem e de certeza, de retirar a ambigüidade, de clarificar, de distinguir, de hierarquizar. Todavia, esse processo necessário à inteligibilidade, pode levar à eliminação de outros caracteres do complexus, tornando-nos cegos.” Diante de tal proposta da complexidade, que adverte sobre os riscos do reducionismo cientificista, impõe-se o enfrentamento transdisciplinar e criativo dos fenômenos.

${ }^{4}$ GAUER, Ruth Maria Chittó. As fronteiras entre certeza e incerteza do conhecimento. In: VASCONCELOS, Maria Lúcia Marcondes Carvalho (Org.). Educação e história da cultura: fronteiras. São Paulo: Mackenzie, 2002, p. 92.
} 
alcance e conteúdo dos conceitos: imparcialidade, verdade, certeza, segurança jurídica - tão caros à atividade jurisdicional, diante da realidade complexa que se apresenta e da impossibilidade de um sistema totalmente justo, surge como alternativa o sistema de garantias, de forma a impedir abusos. Esta mesma conclusão deve ser estendida às decisões judiciais. As possíveis “distorções" que tais decisões, com toda aparência de racionais, possam conter, fornecem, através da fundamentação, um parâmetro, um ponto de partida, para o cotejo com o material probatório existente nos autos e para a discussão.

Efetivamente, é preciso repensar os conceitos da jurisdição estruturados a partir do conhecimento moderno. E mesmo que pareça paradoxal, ao mesmo tempo em que se verifica a relativização destes conceitos por um novo prisma e se constata as fragilidades do processo e das garantias quanto à sua eficácia, fruto de conquistas de tantos séculos da história humana permeada pelo perpétuo embate presente na formação do Estado moderno: poder x liberdade, mais elas se mostram importantes. Por serem frágeis e de alcance material limitado, as garantias devem ser objeto de reflexão e valorização, especialmente no tocante ao que esperar delas e o que podem efetivamente assegurar. Aliás, os maiores detratores das garantias são os primeiros a exigi-las quando delas necessitam. Um dos grandes desafios, assim, será não só universalizá-las, para que as prestações estatais (inclusive pela ação do Judiciário e do acesso à Justiça), ${ }^{5}$ em um crescente, cheguem a todos (inclusive às “vidas nuas”), diminuindo os "vazios de poder" instalados dentro do próprio âmago do Estado, que se propõe ser Democrático e Social de Direito ${ }^{6}$; como também lhes conferir maior eficácia material no âmbito do processo penal.

\section{O DIREITO FUNDAMENTAL À MOTIVAÇÃO DAS DECISÕES JUDICIAIS}

Toda a pessoa chamada a juízo acusada da prática de um delito goza de garantias processuais outorgadas pela Constituição, sendo responsabilidade do próprio Poder Público torná-las efetivas. Assim, cabe ao juiz não só fiscalizar o respeito a estas garantias, mas também promovê-las de modo a torná-las eficazes. ${ }^{7}$

${ }^{5}$ O direito constitucional de acesso à Justiça, previsto no artigo $5^{\circ}$, inciso XXXV, da Constituição Federal,
diretamente vinculado à efetividade do processo, impõe-se em uma sociedade democrática com pretensão
de distribuir justiça a todos. Desta forma, cabe ao Estado propiciar ao cidadão as formas de acesso à
solução de seus problemas, na forma dos incisos LXXIV (direito à assistência jurídica integral e gratuita) e
LXXVII (gratuidade no habeas corpus, no habeas data e, de forma inominada, nos atos necessários ao
exercício da cidadania), do referido artigo $5^{\circ}$.
${ }^{6}$ Como afirma SÁ, Alexandre Franco de. Metamorfose do poder. Coleção Sophia. Coimbra: Ariadne,
2004 , p. 18: “o poder não desaparece, apenas se reconfigura e transforma. Assim, a ausência do poder
político, o espaço vazio deixado pelo desaparecimento de um poder claramente circunscrito e visível, é
apenas uma forma possível da presença de um outro poder”. E nesses “vazios de poder”, segundo
ARENDT, Hanna, Sobre a violência. Rio de Janeiro: Relume-Dumará, 1994, p. 45, como poder e
violência estão em pólos opostos, pode surgir a violência e até, em casos extremos, à própria desaparição
do poder. À mercê destes vazios de poder, desprotegida, encontra-se, na expressão de AGAMBEM,
Giorgio. Homo sacer: o poder soberano e a vida nua. Belo Horizonte: UFMG, 2004. p. 91, a denominada
"vida nua”, ou seja, homens sem direitos, inseguros, não-protegido sob as asas do Leviatã hobbesiano,
vítimas da crise do Estado, caso da população carente.
7 GRINOVER, Ada Pellegrini; FERNANDES, Antonio Scarance; GOMES FILHO, Antonio Magalhães.
As Nulidades no Processo Penal. 7. ed. rev. e atual. São Paulo: Revista dos Tribunais, 2001, p. 27, aduzem 
Como o ordenamento jurídico brasileiro, hierarquizado, tem como fonte originária de direito - a Constituição, duas conseqüências importantes podem daí ser destacadas: não só o processo penal deve estar a ela adequado, de modo que eventual distorção levará à ocorrência de nulidades; como qualquer norma infraconstitucional que restrinja o exercício dos direitos e garantias constitucionais, ferindo a unidade do sistema, poderá ser derrogada pela sua não-recepção pela lei fundamental ${ }^{8}$. Assim, a Constituição estabeleceu garantias de forma a assegurar um processo democrático, onde o Estado possa prestar a tutela jurisdicional efetiva, com o cidadão resguardado de eventuais abusos ou arbitrariedades.

A motivação das decisões decorre do sistema de livre convencimento e da persuasão racional do magistrado, porque abdicados os sistemas da prova legal e da íntima convicção do juiz. ${ }^{9}$ Visa tal garantia, assim, assegurar aos jurisdicionados a ausência de escolhas intuitivas e das conseqüentes decisões arbitrárias, exigindo que o complexo processo de raciocínio (razão e emoção) do julgador possa ser acompanhado. Em nosso ordenamento, a autoridade judiciária não fica adstrita aos elementos coligidos ao feito e tem liberdade na seleção e valoração das provas para proferir a decisão terminativa; entretanto, como garantia do exercício jurisdicional, impõe-se ao operador do direito obrigatoriamente justificar o seu pronunciamento (ainda que seja impossível fazê-lo na sua plenitude), revelando, por assim dizer, a forma como apreendeu os fatos transpostos no processo e as conseqüências que pretende dar a eles. ${ }^{10}$ A explicitação da motivação, com a apreciação dos fatos em toda a sua extensão e profundidade, com respeito e promoção das garantias constitucionais, faz-se necessária, principalmente, no âmbito do processo criminal.

A necessidade de fundamentação do ato não se restringe a uma garantia técnica do processo, sendo vista mais como um princípio de ordem política, isto é, como garantia essencial à administração da justiça em um Estado Democrático de Direito. Através da motivação é possível avaliar o exercício da atividade jurisdicional, verificando as escolhas e seleções feitas pelo julgador para apuração do fato delitivo, a observância das regras do amplo contraditório e, acima de tudo, as circunstâncias

que as garantias constitucionais processuais deixaram de ser exclusivamente direitos subjetivos das partes, ou seja, perderam a idéia individualista, para que, contemporaneamente, adquirissem qualidade do próprio processo, sob o prisma das garantias do devido processo legal. E conclui que os direitos subjetivos constitucionais como ampla defesa, contraditório, juiz natural, motivação, publicidade, entre outros, são, antes de tudo, características de um processo justo e legal, que atua não só em benefício das partes, mas, especialmente, no interesse de todo o corpo social, sendo condição inafastável para uma resposta jurisdicional imparcial, legal e justa.

${ }^{8}$ Ver BOBBIO, Norberto. Teoria do ordenamento jurídico. 6. ed. Brasília: UnB, 1982. p. 49.

${ }^{9}$ Esta última ainda adotada, excepcionalmente, no julgamento pelo Júri.

10 GOMES FILHO, Antônio Magalhães. A motivação das decisões penais. São Paulo: Revista dos Tribunais, 2001, p. 163, define que a motivação judicial consiste em argumentar com a indicação de critérios de inferência, ou seja, das regras que autorizam passar do fato constatado (elementos de prova) à afirmação sobre a real ocorrência (ainda que em termos de probabilidade ou de probabilidade acima de uma dúvida razoável) da hipótese fática debatida no processo. E afirma o autor de maneira ampla que a natureza de tais regras de inferência é diversificada, abrangendo: disposições legais, regras técnicas e científicas, noções consagradas pela experiência comum ou mesmo regras estabelecidas criativamente no próprio procedimento de abdução (silogismo cuja conclusão é apenas provável em decorrência de o ser, também a premissa menor) antes referido. 
factuais extraídas dos autos e que formaram a "verdade do juiz". Destarte, não importa apenas às partes, que podem verificar se suas razões foram objeto de apreciação pelo julgador; mas também ao magistrado, que demonstra sua atuação, e, sobretudo, à sociedade, na medida em que possibilita o acompanhamento sobre a distribuição da justiça de forma igualitária e democrática.

Nesta linha, pontifica Antônio Scarance FERNANDES ${ }^{11}$ que os destinatários da motivação não são mais apenas as partes e os juízes de segunda instância, mas também a comunidade que, através da motivação, tem condições de verificar se o juiz, e assim, a própria Justiça, decide com imparcialidade e com conhecimento de causa. No mesmo sentido, refere Ada Pellegrini GRINOVER: ${ }^{12}$ a motivação é o instrumento pelo qual as partes e o meio social tomam conhecimento da atividade jurisdicional; as partes para, se for o caso, impugnarem os fundamentos da sentença, buscando sua reforma; a sociedade, a fim de que possa formar opinião positiva ou negativa sobre a qualidade dos serviços prestados pela Justiça. A importância do tema é também abordada por Luigi FERRAJOLI, quando apregoa que o valor fundamental da motivação "exprime e ao mesmo tempo garante a natureza cognitiva em vez da natureza protestativa do juízo, vinculando-o, em direito, à estrita legalidade, e, de fato, à prova das hipóteses acusatórias”

E continua o autor:

é por força da motivação que as decisões judiciárias resultam apoiadas, e, portanto, legitimadas, por asserções, enquanto tais verificáveis e falsificáveis ainda que de forma apropriada; que a "validade" das sentenças resulta condicionada à "verdade", ainda que relativa, de seus argumentos; que, por fim, o poder jurisdicional não é o “poder desumano” puramente protestativo da justiça de cadí, mas é fundado no "saber”, ainda que só opinativo e provável, mas exatamente por isso refutável e controlável tanto pelo imputado e sua defesa como pela sociedade. Enquanto assegura o controle da legalidade e do nexo entre convencimento e provas, a motivação carrega também o valor "endoprocessual" de garantia de defesa e o valor "extraprocessual" de garantia de publicidade. E pode ser, portanto, considerado o principal parâmetro tanto da legitimação interna ou jurídica quanto da externa ou democrática da função judiciária. ${ }^{13}$

Objetivando assegurar o devido processo legal e a própria jurisdição em um Estado Democrático, a motivação ganha contornos de direito fundamental, ainda que não esteja prevista entre as garantias expressas no artigo $5^{\circ}$ da Constituição Federal, mas preceituada junto às normas de organização do Poder Judiciário e subentendida nos princípios fundamentais da igualdade, do devido processo legal e da ampla defesa.

${ }^{11}$ FERNANDES, Antonio Scarance. FERNANDES, Antônio Scarance. Processo Penal Constitucional. São Paulo: Revista dos Tribunais, 1999, p. 129.

${ }^{12}$ GRINOVER, Ada Pellegrini; FERNANDES, Antonio Scarance; GOMES FILHO, Antonio Magalhães. Op. cit., p. 212.

${ }^{13}$ FERRAJOLI, Luigi. Direito e razão: teoria do garantismo penal. Tradução de: Ana Paula Zomer, Fauzi Hassan Choukr, Juarez Tavares e Luiz Flávio Gomes. São Paulo: Revista dos Tribunais, 2002. p. 497. 
Neste sentido, afirma Ingo SARLET ${ }^{14}$ que o art. $5^{\circ}$, § $2^{\circ}$, da Constituição Federal,

traduz o entendimento de que, além do conceito formal de Constituição (e de direitos fundamentais), existe um conceito material, no sentido de que existem direitos que, por seu conteúdo, por sua substância, pertencem ao corpo fundamental da Constituição de um Estado, mesmo não constando do catálogo. Neste sentido, é lição pacífica da doutrina que a regra citada implica a impossibilidade de aplicar-se o tradicional princípio hermenêutico do "inclusiu unius alterius est exclusius", o que, em outras palavras, significa que na Constituição também está incluído o que não foi expressamente previsto, mas que implicitamente e indiretamente pode ser deduzido. Doutrina esta que se encontra perfeitamente sedimentada em toda história do constitucionalismo republicano, mas que, nem por isto (e talvez por isto mesmo), não carece de outros desenvolvimentos. ${ }^{15}$

Assim, os direitos fundamentais, efetivamente, não se resumem àqueles elencados no artigo $5^{\circ}$ da Carta (direitos fundamentais em sentido formal), compreendendo os direitos que, apesar de se encontrarem fora do catálogo, ${ }^{16}$ por seu conteúdo e por sua importância (materialmente), podem ser equiparados aos primeiros.

Para Luigi FERRAJOLI a garantia da motivação das decisões, tal como ocorre com as garantias da ampla defesa, do contraditório e da publicidade dos atos processuais, representa uma garantia procedimental que visa assegurar substancialmente a efetivação dos princípios norteadores do sistema garantista de justiça penal, enquanto relativa à formação do juízo, ou seja, à coleta de prova, ao desenvolvimento da defesa e ao convencimento do órgão judicante. ${ }^{17}$ Decorre, em última análise, dos axiomas propostos pelo mestre italiano, os quais, a seu turno, se entrelaçam no conceito de jurisdicionalidade. ${ }^{18}$ De tudo, depreende-se a relevância da percepção do

14 SARLET, Ingo Wolfgang. Valor de alçada e limitação ao acesso ao duplo grau de jurisdição: problematização em nível constitucional, à luz de um conceito material de direitos fundamentais. Revista da AJURIS, Porto Alegre, v. 66, p. 89, 1996.

${ }^{15}$ No mesmo sentido, lecionam Nelson Nery COSTA e Geraldo Magela ALVES que "não obstante a existência de 78 incisos, no artigo $5^{\circ}$, da Constituição de 1988, que tratam de diversos direitos e garantias fundamentais, de acordo com o $\S 2^{\circ}$, desse artigo, existem outros direitos, que decorrem do regime e dos princípios por ele adotados, ou dos tratados internacionais em que a República Federativa do Brasil seja parte. Assim, apesar da exaustiva enumeração de dispositivos constitucionais, foi assegurada a existência de outros direitos relativos à cidadania civil”. COSTA, Nelson Nery; ALVES, Geraldo Magela. Constituição Federal anotada e explicada. Rio de Janeiro: Forense, 2002.

${ }^{16}$ Usamos a expressão “catálogo” no sentido dado por SARLET, Ingo Wolfgang. A eficácia dos direitos fundamentais. 3. ed. rev., atual. e ampl. Porto Alegre: Livraria do Advogado, 2003, p. 126, significando o rol dos direitos e garantias fundamentais expressamente designados como tais pelo Constituinte e que são localizados em todos os capítulos do Titulo II da nossa Carta Magna.

${ }^{17}$ FERRAJOLI, Luigi. Direito e razão: teoria do garantismo penal. Tradução de: Ana Paula Zomer, Fauzi Hassan Choukr, Juarez Tavares e Luiz Flávio Gomes. São Paulo: Revista dos Tribunais, 2002. p. 433.

${ }^{18}$ Segundo Luigi FERRAJOLI, são princípios axiológicos fundamentais, não deriváveis entre si, mas encadeados de maneira que cada um sugere ou insinua, por sua vez, o sucessivo: 1) nulla poena sine crimine, 2) nullum crimen sine lege, 3) nulla lex (poenalis) sine necessitate, 4) nulla necessitas sine injuria, 5) nulla injuria sine actione, 6) nulla actio sine culpa, 7) nulla culpa sine judicio, 8) nullum judicium sine accusatione, 9) nulla accusatio sine probatione, e 10) nulla probatio sine defensione. Dentre os axiomas propostos pelo filósofo italiano ganha destaque, no âmbito processual penal, o princípio da 
magistrado ao analisar o fato delitivo, extraindo dos autos os elementos que lhe pareçam mais adequados à resposta jurisdicional e manifestar o seu sentir (tanto quanto possível) através da fundamentação do ato sentencial, possibilitando ao acusado tomar ciência das garantias constitucionais que foram observadas.

Esse dever de fundamentar as decisões judiciais na esfera penal tem três faces importantes no Estado Democrático de Direito: a) uma garantia de defesa contra eventuais abusos do poder estatal, uma vez que o Julgador deverá explicitar os motivos que o levaram a decidir daquela forma (é um ponto de partida), além de possibilitar a interposição do recurso cabível $;^{19}$ b) a materialização do direito subjetivo à prestação jurisdicional por parte do Estado, após um procedimento marcado por garantias, as quais deverão estar traduzidas na fundamentação; e c) dever do Estado prestá-la, assim como a educação, saúde, segurança, em primeiro e segundo graus de jurisdição, devendo o juiz atuar materialmente no sentido de sua efetivação, sempre sob pena de configuração da nulidade expressamente prevista no texto constitucional. ${ }^{20}$

Desta forma, é possível vislumbrar-se o status da motivação das decisões judiciais como garantia e direito fundamental (com legitimação formal e material), de aplicação imediata (artigo $5^{\circ}$, parágrafo $1^{\circ}$, da Lei Maior), tanto no sentido da limitação do poder como de obter a prestação efetiva da tutela jurisdicional no Estado Democrático de Direito, sob pena de nulidade em caso de sua inobservância. A fundamentação constitucional como disposta no artigo 93, inciso IX, da Constituição Federal, pode ser denominada de "garantia das garantias" ${ }^{21}$, ponto de partida para

jurisdicionariedade (nulla culpa sine judicio), do qual decorrem os princípios acusatório, probatório e o da ampla defesa e do contraditório - garantias asseguradas no ordenamento jurídico pátrio. FERRAJOLI, Luigi. Direito e razão: teoria do garantismo penal. Op. cit., p. 74-75.

${ }^{19}$ E o conceito de recurso que se adota não é o que toma o vocábulo latino "recursus" como "corrida para trás, caminho para voltar, volta” (TOURINHO FILHO, Fernando da Costa. Processo penal. V. 4. São Paulo: Saraiva, 2004, p. 247), mas sim, o que prioriza a nova visão, sempre presente no caso de uma motivação compartilhada. Affonso BRAGA destaca a partícula iterativa de origem desconhecida "re", que significa não apenas volta, mas também, "renovação” (BRAGA, Affonso. Instituições de processo civil no Brasil. V. 3. Rio de Janeiro: Forense, 1941. p. 7)

${ }^{20}$ Segundo CANOTILHO, deve existir uma dinâmica dialética entre os direitos fundamentais e o princípio democrático. Primeiro, pressupondo a participação igual dos cidadãos, o princípio democrático entrelaçase com os direitos subjetivos de participação e associação, que se tornam por conseqüência fundamentos funcionais da democracia. Os direitos fundamentais, ao depois, na medida em que consistem em direitos subjetivos de liberdade, criam um espaço contra o exercício de poder antidemocrático. Terceiro, alude o autor português que, “como direitos legitimadores de um domínio democrático, os direitos fundamentais asseguram o exercício da democracia mediante a exigência de garantias de organização e de processos com transparência democrática”. Por fim, como direitos subjetivos a prestações sociais, econômicas e culturais, os direitos fundamentais "constituem a força dirigente para o preenchimento intrínseco, através do legislador democrático, desses direitos”. Embasado nestas quatro premissas, sustenta que os direitos fundamentais são, ao mesmo tempo, elemento constitutivo do Estado de Direito e elemento básico para a realização do princípio democrático. CANOTILHO, José Joaquim Gomes. Direito Constitucional. CANOTILHO, Joaquim José Gomes. Direito Constitucional. 5. ed. Coimbra: Almedina, 1992, p. 349.

${ }^{21}$ A motivação das decisões judiciais, enquanto garante o controle da legalidade e do nexo entre convencimento e provas, carrega também o valor endoprocessual de garantia de defesa e extraprocessual de garantia da publicidade, de modo a poder ser considerado o principal parâmetro tanto de legitimação inteerna ou jurídica quanto da externa ou democrática da função judiciária. (FERRAJOLI, Luigi. Direito e razão: teoria do garantismo penal. Op. cit., p. 498) 
análise do respeito a todos os demais direitos constitucionais do acusado. Portanto, esta "garantia-mãe" constitui instrumento essencial de observância e revelação do respeito a outras expressamente catalogadas, devendo ser vista de maneira mais ampla no processo penal, como forma de emprestar-lhe maior eficácia material.

Esta idéia é sustentada, legislativamente, não só a partir da referida abertura material autorizada pelo parágrafo $2^{\circ}$ do artigo $5^{\circ}$ da Constituição Federal, mas também do enfoque conjunto de garantias ligadas à “motivação”, de onde se extrai parâmetros de interpretação sistemática do seu alcance e se articulam relações dotadas de maior complexidade. Na expressão de Antônio Magalhães GOMES FILHO, ocorre, assim, "uma interpenetração recíproca de princípios, de tal forma que uns conferem efetividade a outros e são por estes reforçados, dando lugar a um sistema apto a assegurar, em níveis cada vez mais elevados, a proteção do indivíduo por meio do processo". ${ }^{22}$

\section{A MOTIVAÇÃO COMO COROLÁRIO DE OUTRAS GARANTIAS CONSTITUCIONAIS}

Conferem especial suporte à “motivação" no processo penal como direito fundamental, o princípio da dignidade da pessoa humana e as seguintes garantias: devido processo legal, contraditório e ampla defesa, presunção de inocência, bem como o duplo grau de jurisdição que possibilita a aplicação do compartilhamento decisório nas sentenças penais condenatórias monocráticas, potencializando a eficácia material das demais garantias.

\subsection{Dignidade da pessoa humana}

Ao passar à análise, inicialmente, deve-se considerar que, a teor do disposto no artigo $1^{\circ}$ da Constituição Federal, ${ }^{23}$ a República Federativa do Brasil constitui-se em um Estado Democrático de Direito, destacando entre seus fundamentos o reconhecimento da dignidade da pessoa humana, que vem a ser, segundo esclarece Ingo Wolfgang SARLET, ${ }^{24}$

a qualidade intrínseca e distintiva de cada ser humano que o faz merecedor do mesmo respeito e consideração por parte do Estado e da comunidade, implicando, neste sentido, um complexo de direitos e deveres fundamentais que assegurem a pessoa tanto contra todo e qualquer ato de cunho degradante e desumano, como venham a lhe garantir as condições existenciais mínimas para uma vida saudável, além de propiciar e promover sua participação ativa e co-responsável nos destinos da própria existência e da vida em comunhão com os demais seres humanos.

Ao perfilhar a dignidade como princípio fundamental, o texto constitucional encerra normas que outorgam direitos subjetivos de cunho negativo, isto é, de nãoviolação da dignidade, e simultaneamente impõem condutas positivas, no sentido de

${ }^{22}$ GOMES FILHO, Antônio Magalhães. Op. cit., p. 32-33.

${ }^{23}$ Dispõe o artigo $1^{\circ}$, inciso III, da Constituição de 1988: “A República Federativa do Brasil, formada pela união indissolúvel dos Estados e Municípios e do Distrito Federal, constitui-se em Estado Democrático de Direito e tem como fundamentos: a dignidade da pessoa humana”.

${ }^{24}$ SARLET, Ingo Wolfgang. Dignidade da pessoa humana e direitos fundamentais na Constituição Federal de 1988. 2. ed. rev. ampl. Porto Alegre: Livraria do Advogado, 2002, p. 60. 
proteger e promover a dignidade da pessoa. Desta forma, para o autor, ${ }^{25}$ quando se fala em direito à dignidade estamos nos referindo ao direito a reconhecimento, respeito, proteção e até mesmo promoção e desenvolvimento desta dignidade, podendo, inclusive, sustentar-se um direito à existência digna. Em vista disto, é possível entendê-la como um valor revelador da ordem jurídica do Estado e uma qualidade intrínseca da pessoa humana, de modo que não pode a sua observância ficar condicionada à previsão legal, ou seja, à concessão pelo ordenamento jurídico. Ainda que preexista ao direito, o reconhecimento e proteção da dignidade por parte do Estado conferem legitimidade à garantia.

Sobre a relevância do princípio em tela, destaca Jayme WEINGARTNER $\mathrm{NETO}^{26}$ que

não se trata de mera e solene declaração ético-moral. Ao revés, dotado de eficácia, é valor jurídico fundamental da comunidade, em face da decisão constitucional, valor-guia que se tem caracterizado como o princípio constitucional de maior hierarquia axiológica-valorativa.

Da mesma forma, para Tadeu Antonio Dix SILVA, ${ }^{27}$

o princípio da dignidade humana deve ser interpretado como uma esfera constitutiva da República brasileira, visto que esse postulado espelha um reflexo por todos os direitos e garantias fundamentais, constituindo toda a viga mestra do arcabouço jurídico, porque confere unidade de sentido ao conjunto de preceitos relativos aos direitos fundamentais e tem de ser interpretado como referido "a cada pessoa (individual), a todas as pessoas sem discriminação (universal) e a cada homem com um ser autônomo (livre)".

Impõe-se, por tal razão, seja este o princípio condutor da motivação como garantia constitucional aqui proposta. Os direitos e garantias fundamentais, igualmente adotados pelo ordenamento pátrio como núcleo primário da atuação estatal, dispostos no Título II da Carta Constitucional, encontram-se intimamente relacionados ao princípio da dignidade da pessoa humana. ${ }^{28}$ A dignidade configura valor essencial que pressupõe o reconhecimento e proteção dos direitos fundamentais de todas as dimensões, de forma que, sem o reconhecimento à pessoa humana dos direitos fundamentais que lhe são inerentes, estaremos lhe negando a própria dignidade.

Desta forma, seja pelo fato de que cada direito fundamental se encontra projetado

${ }^{25}$ SARLET, Ingo Wolfgang. Dignidade da pessoa humana e direitos fundamentais na Constituição Federal de 1988. Op. cit., p. 71.

${ }^{26}$ WEINGARTNER NETO, Jayme. Honra, privacidade e liberdade de imprensa - uma pauta de justificação penal. Porto Alegre: Livraria do Advogado, 2002. p. 123.

${ }^{27}$ SILVA, Tadeu Antonio Dix. Liberdade de expressão e Direito Penal no Estado Democrático de Direito. São Paulo: IBCCrim, 2000, p. 53-54.

${ }^{28}$ Nesse mesmo sentido CARVALHO, Luis Gustavo Grandinetti Castanho. Processo Penal e Constituição. Princípios Constitucionais do Processo Penal. Rio de Janeiro: Lumen Juris, 2004. p. 30. 
de alguma forma no princípio da dignidade da pessoa humana, ${ }^{29}$ seja porque já do Preâmbulo da Constituição é possível se verificar como finalidade do Estado Democrático brasileiro assegurar o exercício: "dos direitos sociais e individuais, a liberdade, a segurança, o bem-estar, o desenvolvimento, a igualdade, a justiça como fundamentos de uma sociedade fraterna, pluralista e sem preconceitos (...)”, a garantia à motivação no processo penal deve encontrar na dignidade da pessoa humana um de seus sustentáculos como garantia fundamental.

\subsection{Devido processo legal}

Além da dignidade da pessoa humana, outros princípios concorrem para estabelecer o status de garantia constitucional destacada à motivação. Segundo COUTURE, ${ }^{30}$ o "devido processo legal" (due process of law), resume-se em assegurar à pessoa a possibilidade de se defender em juízo, de modo que não seja privada da liberdade e de seus bens, sem as garantias que pressupõem a tramitação de um processo, na forma que a lei estabelece. Para Paulo RANGEL, ${ }^{31}$ o princípio significa que para haver cerceamento de liberdade (seja ela qual for) ou para que alguém seja privado de seus bens, devem ser respeitadas todas as formalidades previstas em lei. E como afirma Nereu GIACOMOLLI ${ }^{32}$ de maneira mais ampla, o “devido processo constitucional” traz consigo a exigência no processo penal de uma série de medidas: a) a oportunização da defesa pessoal e a obrigatoriedade da defesa técnica; b) uma decisão motivada; c) uma citação válida; d) a presença nos atos processuais; e) a imediata apresentação do réu a juízo; f) a possibilidade de entrevistar-se com o advogado antes de ser interrogado; a presença de advogado no interrogatório e em todos os demais atos processuais; g) não ser compelido a produzir prova contra si mesmo; h) ser acusado pelo representante estatal destinado na respectiva unidade judiciária e não pela conveniência administrativa e/ou casuística.

Por outro lado, a garantia em tela engloba no processo penal a do "acesso à justiça criminal”, ${ }^{33}$ prevista no inciso XXXV do artigo $5^{\circ}$ da Constituição Federal

\footnotetext{
${ }^{29}$ Como afirma Ingo SARLET, os direitos fundamentais “constituem - ainda que com intensidade variável - explicitações da dignidade da pessoa, por via de conseqüência e, ao menos em princípio, em cada direito fundamental se faz presente um conteúdo ou, pelo menos, alguma projeção da dignidade da pessoa”. SARLET, Ingo Wolfgang. Dignidade da pessoa humana e direitos fundamentais na Constituição Federal de 1988. Op. cit., p. 87.

${ }^{30}$ COUTURE, Eduardo J. Fundamentos del derecho procesal civil. 3. ed. Buenos Aires: DEPALMA, 1972. p. 45.

${ }^{31}$ RANGEL, Paulo. Direito Processual Penal. Rio de Janeiro: Lumen Juris, 2004, p. 2.

32 Nereu José GIACOMOLLI bem utiliza a denominação “devido processo constitucional”, uma vez que “o processo legal e devido a ser seguido, é o constitucionalmente válido”. GIACOMOLLI, Nereu José. Juizados Especiais Criminais: Lei 9.099/95. 2. ed. Porto Alegre: Livraria do Advogado, 2002. p. 51.

${ }^{33} \mathrm{O}$ direito à reapreciação do veredicto encontra-se também compreendido na garantia constitucional de acesso à justiça, denominada também como princípio da inafastabilidade ou do controle jurisdicional, ou, ainda, consoante designado por Luigi FERRAJOLI como princípio da jurisdicionalidade. Ditada no inciso XXXV do artigo $5^{\circ}$ da Constituição Federal, tal garantia assegura ao cidadão a apreciação pelo Poder Judiciário de qualquer lesão ou ameaça de lesão a direito, por atos de particulares ou agentes públicos, impedindo inclusive que o magistrado escuse-se de proferir decisão. FERRAJOLI, Luigi. Direito e razão: teoria do garantismo penal. Op. cit., p. 74-75.
} 
(“a lei não excluirá do Poder Judiciário lesão ou ameaça a direito”), essencial à efetividade do processo em uma sociedade democrática que se propõe a distribuir justiça a todos os segmentos sociais. Tal garantia, conforme Rogério Lauria TUCCI, deve incluir tanto a acessibilidade econômica, representada na assistência jurídica gratuita aos necessitados, como a acessibilidade técnica relativa à efetividade da defesa deduzida pelo profissional habilitado. ${ }^{34}$ Sua relação com o direito à "motivação" é evidente, uma vez ser necessária à sua eficácia material, em se tratando de sentenças condenatórias na seara penal, a possibilidade de amplo acesso à instância superior através da interposição do recurso cabível.

Assim, o “devido processo legal” é o caminho que deve ser percorrido até que se possa privar alguém de sua liberdade ou de seus bens, mediante a devida e suficiente motivação. Ao trilhar este caminho no processo penal espera-se do juiz, em um Estado Democrático de Direito, uma postura ativa (de poder e contrapoder), no sentido de zelar para que os direitos constitucionais do réu sejam efetivamente respeitados, até o provimento final (de onde é possível se falar em um devido processo constitucional). A inobservância das garantias constitucionais que devem ser observadas no decurso do devido processo legal implica imediata violação a este princípio.

\subsection{Contraditório e ampla defesa}

Entre as garantias constitucionais mais proeminentes no devido processo legal, ${ }^{35}$ e a merecer destaque para fins da motivação como direito fundamental, estão o contraditório $^{36}$ e a ampla defesa (artigo 50, $\mathrm{LV}$, da Constituição). Como afirma

\footnotetext{
${ }^{34}$ Rogério Lauria TUCCI analisa a garantia constitucional de acesso à justiça, no que tange à jurisdição criminal, sob dois enfoques: acessibilidade econômica e acessibilidade técnica. Quanto ao direito à assistência jurídica integral e gratuita, o mesmo autor aduz que a nossa Constituição ao estabelecer no art. $5^{\circ}$, caput, o direito à igualdade com um dos direitos fundamentais, a tutela jurisdicional do Estado somente será uma efetiva e real, se colocada ao alcande de todos, sem qualquer restrição, assim se impõe a gratuidade do processo aos menos favorecidos economicamente, através da garantia a assistência judiciária, prevista no art. 5º LXXIV, da Constituição Federal. TUCCI, Rogério Lauria. Direitos e garantias individuais no processo penal brasileiro. São Paulo: Saraiva, 1993, p. 95. No mesmo diapasão, Ada Pellegrini GRINOVER destaca que o dever do Estado de prestar assistência judiciária aos necessitados e garantir igual acesso à Justiça, deve ser visto em um panorama mais amplo: "como prestação positiva do Estado Social de Direito”. GRINOVER, Ada Pellegrini. Novas tendências do Direito Processual. Rio de Janeiro: Forense, 1990. p. 243-244.

${ }^{35}$ Neste sentido, esclarece Márcia Dometila Lima de CARVALHO que o devido processo legal é de compreensão bastante ampla, dele se deduzindo vários outros princípios ou regras de caráter processual penal: "Este super-princípio, desdobrado em princípios processuais outros como o do juiz natural (inciso LIII do art. $5^{\circ}$ da C.F.), o da publicidade das audiências (inciso LX, artigo $5^{\circ}$ da C.F.), o da presunção de inocência (inciso LVII do artigo $5^{\circ}$ da C.F.), do qual decorrem outros princípios processuais como o do in dúbio pro reo, o do contraditório e o da ampla defesa, transformam o processo penal em verdadeira garantia de liberdade, vinculando a relação e assegurando, às partes, os respectivos processo e jurisdição”. CARVALHO, Márcia Dometila Lima de. Fundamentação Constitucional do Direito Penal. Porto Alegre: Sérgio Antonio Fabris, 1992. p. 78.

${ }^{36}$ Rogério Schietti Machado CRUZ assevera que a adoção do princípio do contraditório como método heurístico no processo penal moderno consiste, basicamente, na necessidade de conferir iguais oportunidades às partes de serem ouvidas pelo órgão jurisdicional competente, em virtude de cada pronunciamento da parte contrária. CRUZ, Rogério Schietti Machado. Garantias processuais nos recursos criminais. São Paulo: Atlas, 2002. p. 169.
} 
Nereu GIACOMOLLI, ${ }^{37}$ o direito à ampla defesa, instituído não só como garantia individual, mas da própria sociedade, "é princípio basilar do processo penal democrático, do qual se extraem outras garantias, como é o caso do contraditório. Essa defesa, portanto, deve ser efetiva, uma antítese firme e consistente à tese da acusação, não bastando a simples nomeação ou constituição de defensor que, apesar de tecnicamente habilitado, por desconhecer as possibilidades fáticas e jurídicas dos autos, deduza alegações meramente abstratas e genéricas. Sempre que houver ausência ou deficiência de defesa, deve ser examinado o alcance desta violação e se o defeito impediu a produção do resultado próprio do ato em prejuízo do acusado. Neste último caso, não haverá reconhecimento de que houve defesa ainda que considerada existente do ponto de vista formal. Da mesma forma, o contraditório deve ser garantido pelo juiz no caso concreto. Constitui-se na essência do processo jurisdicional, onde "tese e antítese, voz ativa e voz passiva, pedido e contrapedido, ataque e defesa, culpado ou inocente, igualdade de meios de acusar e de se defender".

Assim, o disposto no 5 , inciso LV, da Constituição Federal: “aos litigantes, em processo judicial ou administrativo, e aos acusados em geral são assegurados o contraditório e a ampla defesa, com os meios e recursos a ela inerentes”, vigora em favor do acusado, como em todo o processo do tipo acusatório. ${ }^{38} \mathrm{O}$ réu deve conhecer os termos da acusação que lhe atribuída pra poder contrariá-la e defender-se (o que inclui a autodefesa, mas especialmente, a defesa técnica). Relacionadas ao contraditório e à ampla defesa estão, não só outras garantias constitucionais, como à igualdade processual (artigo $5^{\circ}$, caput), ao juiz natural ${ }^{39}$ (5 $^{\circ}$, LIII), ao direito de silenciar ( $5^{\circ}$, LXIII), à fundamentação e à publicidade (93, IX), à assistência jurídica integral aos necessitados (art. 5 $5^{\circ}$ LXIV), mas também relativos à jurisdição, como a imparcialidade do juiz, a persuasão racional e o direito de recorrer das decisões. Íntima, portanto, é sua relação com a motivação, uma vez que amplia não só a visibilidade e o debate sobre os fatos da causa, como também as chances de contraditar a acusação e deduzir a defesa.

\footnotetext{
${ }^{37}$ GIACOMOLLI, Nereu José. Op. cit., p. 48-50. Para o autor a ampla defesa abrange a defesa técnica e a pessoal, sendo que esta não é obrigatória em razão do direito ao silêncio.

${ }^{38}$ Segundo Giampaolo SMANIO, o sistema acusatório, já referido várias vezes ao longo deste trabalho, não apresenta os mesmos defeitos dos juizados de instrução em que a imparcialidade do juiz é afetada, pois este não atua como sujeito ativo na produção da prova, ficando a salvo de comprometimentos psicológicos prévios. Este sistema pressupõe as seguintes garantias constitucionais: tutela jurisdicional ( $\left.5^{\circ}, \mathrm{XXXV}\right)$, devido processo legal ( $\left.5^{\circ}, \mathrm{LIV}\right)$, garantia do acesso à justiça ( $\left.5^{\circ}, \mathrm{LXXIV}\right)$, juiz natural ( $5^{\circ}$, XXXVII e LIII), isonomia ( $5^{\circ}$, caput e I); da ampla defesa (5 $5^{\circ}, \mathrm{LV}, \mathrm{LVI}$ e LXII), publicidade dos atos processuais e motivação dos atos decisórios (93, IX) e presunção de inocência ( $5^{\circ}$, LVII). SMANIO, Giampaolo Poggio. Criminologia e juizado especial criminal. São Paulo: Atlas, 1997. p. 31-38 e 51.

${ }^{39}$ TUCCI, Rogério Lauria e TUCCI, José Rogério Cruz e. Constituição de 1988 e processo. São Paulo: Saraiva, 1989. p. 30. Os autores comentam o significado do princípio de juiz natural e anotam que “... no subseqüente inc. LIII encontra-se ela preceituada, também com toda clareza, ao soar o dispositivo que ninguém será processado nem sentenciado senão pela autoridade competente. E, desse modo, firma-se, explicitamente, tanto no âmbito do processo civil, como no do processo penal, a exigência de preconstituição do órgão jurisdicional competente, entendendo-se este como o agente do Poder Judiciário, política, financeira e juridicamente independente, cuja competência esteja previamente delimitada pela legislação em vigor”.
} 


\subsection{Presunção de inocência}

Também a embasar a "motivação" há que se referir, ainda, o princípio da presunção de inocência ${ }^{40}$ que, nas palavras de TOURINHO FILHO, ${ }^{41}$ representa um coroamento do “devido processo legal”, como ato de fé no valor ético da pessoa, próprio de toda a sociedade livre. Contemporaneamente, tal princípio insere-se em um quadro mais amplo de garantias, como aduz Antônio Magalhães GOMES FILHO, ${ }^{42}$ não somente do cidadão individualmente considerado, mas também e, sobretudo, do próprio exercício da atividade jurisdicional. Destaca-se, ainda, sua aceitação como pressuposto indispensável da persecução penal no Estado Democrático de Direito e a necessidade de objetivar a superação de desigualdades sociais que são naturalmente trazidas para o âmbito do processo, assegurando-se uma "efetiva paridade de armas". Efetivamente, ganha espaço, ainda que de maneira incidental na análise desta garantia fundamental, o já referido dever prestacional por parte do Estado de garantir o direito à assistência jurídica integral e gratuita aos que demonstrarem insuficiência de recursos (art. 5, LXXIV, da Constituição Federal), no sentido de emprestar meios para que a parte mais carente (ainda regra no processo penal brasileiro), possa, na guerra do processo, manter este seu estado de inocência.

Nesta mesma linha, quando se trata de motivação, avulta a importância do mais destacado princípio informador do processo penal brasileiro: o "favor rei", 43 segundo

40 JIMENEZ, Hernando Londoño. Derecho procesal penal. Bogotá: Têmis, 1982. p. 29-39. O autor diz que, atualmente, se entende que existe um “estado de inocência”, isto é, um estado jurídico no qual o réu é inocente até que seja declarado culpado por uma sentença transitada em julgado. Por sua vez, MEDEIROS, Flávio Meirelles. Princípios de Direito Procesual Penal. Porto Alegre: Ciências Jurídicas, 1984, p. 82, acrescenta que, no sentido processual, a inocência não existe como uma presunção, e esclarece que não há juízo de inocência ou suposição de inocência, mas sim a situação jurídica processual de inocência. Já Antônio Magalhães GOMES FILHO (Op. cit. p. 84) aduz que a garantia constitucional da presunção de inocência se impõe como regra de tratamento ao suspeito, indiciado ou acusado, que antes da condenação não pode sofrer qualquer espécie de equiparação ao culpado. Nesta tese utiliza-se a expressão "presunção de inocência”, pois de acordo com o teor da Súmula 09 do Superior Tribunal de Justiça.

${ }^{41}$ TOURINHO FILHO, Fernando da Costa. Processo Penal. Op. cit., p. 61.

${ }^{42}$ GOMES FILHO, Antônio Magalhães. Presunção de inocência prisão cautelar. São Paulo: Saraiva, 1991. p. 85

${ }^{43}$ BETTIOL, Giuseppe. Instituciones de derecho penal y procesal. Barcelona: Bosch, 1977. p. 262. Segundo o autor, o princípio do favor rei está presente em todo Estado autenticamente regido pelos valores da democracia, da liberdade e da dignidade humana. De maneira mais ampla, Fernando da Costa TOURINHO FILHO (Processo penal. Op. cit., p. 71-73), afirma que o princípio do favor rei, possui íntima vinculação com a presunção de inocência, basilar à interpretação de toda legislação processual penal de um Estado Democrático, inspirado por um ideal de liberdade e voltado à dignidade da pessoa humana, quando em conflito o direito de punir do Estado e o direito de liberdade de outro, este deve prevalecer. Assim, nos casos de impossibilidade de uma interpretação unívoca ou de antinomias interpretativas, deve ser escolhida a mais benéfica ao réu. Este princípio tem maior aplicação exatamente em sede recursal, como no caso de previsão de recursos exclusivos da defesa (como o protesto por novo júri e os embargos infringentes e de nulidade, previstos, respectivamente, nos artigos 607 e 609, parágrafo único, ambos do Código de Processo Penal); da proibição da reformatio in pejus (art. 617 do Código de Processo Penal); da revisão criminal como ação privativa da defesa (artigos 621 e seguintes do Código de Processo Penal); da regra do artigo 615, parágrafo $1^{\circ}$, do Código de Processo Penal e habeas corpus como dos recursos privativos da defesa. Há também o direito do réu silenciar - nemo tenetur se detegere (artigo $5^{\circ}$, inciso LXIII, da Carta Magna e 186 do Código de Processo Penal) e, o in dúbio pro reo, previsto no artigo 386, inciso VI, do Código de Processo Penal, de grande importância, pois a dúvida, tão possível diante das 
o qual sempre a dúvida beneficia o acusado, de forma que se houver mais de uma interpretação possível, a escolhida deverá ser a mais benéfica. ${ }^{44} \mathrm{Na}$ dúvida, absolve-se o acusado por insuficiência de provas, na forma do art. 386, inciso VI, do aludido diploma penal adjetivo. Sem contar que, à luz de tal princípio, apenas a defesa dispõe de certos recursos (como o protesto por novo júri e os embargos infringentes) e ações (revisão criminal, hábeas corpus). A soma do princípio da presunção de inocência, com o "favor rei" - diante das incertezas do conhecimento atual, especialmente a partir da complexidade decorrente do risco exógeno (social) e endógeno (processual); da relativização do conceito de verdade (inclusive com a vedação de certas provas e medidas processuais contra o réu); das exigências de cada vez maior velocidade e produtividade por parte do julgador (transferência do tempo social para o tempo do processo que é outro, do ritual); e das limitações probatórias na recognição dos fatos ocorridos - ganha especial relevo.

Para um juízo condenatório na seara penal, assim, não só deve ser provado o que alega a acusação, mediante o estrito respeito às garantias, mas, sobretudo, afastado este estado de dúvida que milita em favor do réu. ${ }^{45}$ A “dúvida” não é um estado negativo, ineficaz ou inidôneo, mas sim, positivo. Como afirma Santiago Sentis MELENDO sobre o referido princípio em favor do réu, "quando o juiz absolve não está em dúvida, está seguro de que faltam provas para condenar. Não se trata de favor, mas de justiça” ${ }^{46}$ Portanto, a motivação no processo penal não só impede que o "estado de inocência” do réu condenado em primeira instância seja ceifado prematuramente, como também, amplia a possibilidade de visualização da dúvida e, assim, da prolação de um juízo absolutório. Finalmente, resta examinar, de maneira mais extensa, diante de sua especial relevância para a eficácia material do direito fundamental à motivação, a garantia constitucional dos réus condenados em primeira instância ao "duplo grau de jurisdição". ${ }^{47}$

\subsection{Duplo grau de jurisdição}

Tal garantia objetiva respaldar o conteúdo democrático da persecução criminal, razão porque compreende as garantias do contraditório, da imparcialidade do julgador, da publicidade dos atos e da motivação das decisões. Juntamente com tais garantias instrumentais, e como corolário lógico do direito à plenitude de defesa, é que surge o

incertezas do conhecimento trazidas ao longo desta tese, deve levar à absolvição do réu, a demonstrar, com veemência, a importância do compartilhamento decisório em matéria processual penal.

${ }^{44}$ RANGEL, Paulo. Direito Processual Penal. Op. cit., p. 34.

${ }^{45}$ Como esclarece Nereu José GIACOMOLLI (Op. cit, p. 52), "o princípio da inocência se refere tanto ao conteúdo da sentença, como aos atos processuais que induzem esse conteúdo, como é o caso dos atos probatórios e da motivação judicial, incumbindo à acusação o ônus probante da quebra da inocência. Assim, esse princípio somente pode ser rompido com prova legítima produzida sob as garantias constitucionais”. ${ }^{46}$ MELLENDO, Santiago Sentís. In dubio pro reo. Buenos Aires: EJEA, 1971. p. 158.

${ }^{47}$ Como destaca CRUZ, Rogério Schietti Machado. Garantias processuais nos recursos criminais. São Paulo: Atlas, 2002, p. 57, após pesquisar as Constituições de dezenas de países (Alemanha, Argentina, Chile, China, Cuba, Espanha, estados Unidos da América, França, Grã-Betanha, Guiné-Bissau, Itália, Japão, México, Paraguai, Peru, Portugal, Suiça, Uruguai e Venezuela) foi possível constatar que o princípio do duplo grau de jurisdição não está previsto de forma expressa, embora possa ser identificado nas leis fundamentais da grande maioria dos povos. 
direito do indivíduo de recorrer da decisão monocrática que lhe é desfavorável, logrando, com isto, um segundo olhar sobre o veredicto. No sentido de considerar a garantia ao duplo grau de jurisdição ${ }^{48}$ abrangido pelo disposto no artigo $5^{\circ}$, inciso XXXV, da Constituição Federal (acesso à jurisdição), afirma Ingo SARLET ${ }^{49}$ que, como a lesão ou risco ao direito pode decorrer de ato do próprio Judiciário, esta garantia constitucional fundamental estaria ameaçada de inoperância caso não fosse possível, de alguma forma, sua revisão. Assim, o direito à proteção judiciária vem sendo aplicado como abrangente do "direito à proteção efetiva e razoavelmente eficaz", mas através do juiz e não contra ele, o que exclui, desta forma, do espectro de proteção da norma, a garantia a uma segunda ou terceira instância. Contudo, no primeiro caso, não se estaria criando um novo direito fundamental, mas preenchendo o âmbito protetivo de uma norma já existente, interpretando-a em sintonia com o sistema constitucional positivo. Além da norma do art. $5^{\circ}$, inciso XXXV, da Carta Magna, seria possível cogitar-se de uma interpretação sistemática harmônica com outros dispositivos do mesmo artigo, nomeadamente, os incisos LIV (devido processo legal) e LV (ampla defesa). Apenas este último, isoladamente, já poderia (quanto mais somado com o inciso XXXV), abranger a garantia da possibilidade de acesso a uma segunda instância e de recorrer das decisões judiciais (pelo menos como regra geral e, no caso desta tese, de sentenças penais condenatórias monocráticas). E completa o autor:

\footnotetext{
${ }^{48}$ Segundo Rogério Schietti Machado CRUZ (Op. cit., p. 58), a existência do duplo grau, tradicionalmente, justifica-se pelos seguintes motivos: a) controle da qualidade das decisões judiciais por órgão superior; b) ganho de confiabilidade no sistema, uma vez que o juiz, sabendo que seus atos podem ser revistos por outros pares, esmera-se em melhor julgar; c) maior experiência e tirocínio dos julgadores em segunda instância, o que acarreta melhores condições para o julgamento; d) decisão colegiada, chegando-se ao veredicto sem as limitações de uma única mente. E apesar do fato da existência de dois graus tornar a justiça mais lenta, hierarquizada e, até, contraditória nas situações em que as diferentes instâncias não produzem o mesmo veredicto, seria temerário, pelo prisma do acusado de um delito, suprimir-lhe o direito ao duplo grau. Por outro lado, o Estado de Direito Democrático não se compatibiliza com a idéia de um processo penal pautado por juízo único, alheio ao controle interno das partes. Antônio Magalhães GOMES FILHO. Op. cit., p. 44-48), diz não ser consensual a inclusão do “duplo grau de jurisdição” entre os pressupostos essenciais à realização de um processo justo, destacando como argumentos contrários: a) um perfil histórico tem demonstrado que a previsão de recursos que possibilitem a completa reapreciação de matérias decididas em primeiro grau acompanha ordenamentos de índole totalitária, tendo-se como exemplo a origem romana da apelação no período imperial; b) procrastinação de demandas; c) incertezas jurídicas; d) desprestígio do Poder Judiciário com a reforma das decisões; e) uma decisão por ser de magistrado de hierarquia superior não necessariamente é melhor que a do julgador monocrático que teve contato com as partes e as provas). Mas segundo o autor, não se pode deixar de incluir entre as garantias processuais o reexame das decisões, em seus aspectos de fato e de direito, ou o duplo grau de jurisdição. Destacamos, ainda, a possível riqueza agregada pelo compartilhamento, onde os julgadores, terão a chance, na lição de Habermas, à comunicação intersubjetiva, com aumento de visibilidade sobre aspectos fáticos e jurídicos do julgado, sem apego a essa pré-conotação cartesiana dual e restritiva de decisão melhor ou pior.

49 SARLET, Ingo Wolfgang. Valor de alçada e limitação ao acesso ao duplo grau de jurisdição: problematização em nível constitucional, à luz de um conceito material de direitos fundamentais. Op. cit., p. 117-118. Refere como exemplo o autor, tanto a jurisprudência da Corte Constitucional Federal Alemã, no sentido da elasticidade que tem dado à interpretação, embora sem previsão do acesso ao duplo grau como direito fundamental, do direito à proteção judiciária e ao acesso à justiça; como do Tribunal Constitucional Português, o qual, reconheceu um direito de recurso ao segundo grau de jurisdição.
} 
Sem dúvida, há como sustentar o entendimento de que a possibilidade de se ter reexaminada uma decisão parcial ou totalmente desfavorável harmoniza-se com as exigências do princípio da ampla defesa, bem como com a eficácia (no sentido de maior confiabilidade e segurança) dos julgamentos e também do acesso à justiça. ${ }^{50}$

Todos os cidadãos e o Ministério Público têm garantido o direito ao reexame das sentenças. No entanto, trata-se, basicamente, uma garantia de defesa fundamental no processo penal, uma vez que o erro e a injustiça trazem conseqüências particularmente graves neste ramo do Direito, onde, além da liberdade, está em jogo a própria dignidade pessoal do acusado, o que constitui valor fundamental em um Estado Democrático de Direito. Se, de um lado, a revisão das decisões constitui uma proteção do indivíduo contra o exercício abusivo ou arbitrário do poder-dever do Estado de repressão às condutas tidas como lesivas ao viver em sociedade, de outro, surge com o próprio homem no exato momento em que se sente injustiçado, incompreendido e perseguido, e busca a reparação de sua “dor” através de uma nova apreciação da questão. ${ }^{51} \mathrm{O}$ reexame do ato decisório propõe-se, enfim, à satisfação de uma tendência do ser humano de não se conformar com um julgamento que lhe é desfavorável. ${ }^{52}$

${ }^{50}$ O Supremo Tribunal Federal têm negado o duplo grau como garantia constitucional fora das hipóteses estabelecidas em lei, sob o argumento da primazia da Constituição em relação a tratados e convenções internacionais. Conforme decisão da excelsa Corte (Recurso em Habeas Corpus 79785/RJ, Rel. Ministro Sepúlveda Pertence, j. 29.03.2000 - publicada no Informativo $n^{\circ}$ 183, de 27 a 31.03.2000), não cabe em processo criminal de competência originária do Tribunal de Justiça a interposição de recurso para o Superior Tribunal de Justiça para reexame de matéria fática. Tendo sido invocado com base no princípio da isonomia e no duplo grau de jurisdição, este último conforme o disposto no artigo $8^{\circ}$, 2, do Pacto de San José da Costa Rica, foi negado pelo entendimento de que a Constituição Federal de 1988 enumera taxativamente os recursos cabíveis para o Supremo Tribunal Federal e o Superior Tribunal de Justiça. Essa convenção possui natureza de lei ordinária não estando a Lei Maior, portanto, obrigada a observar suas disposições, além do que o duplo grau não é uma garantia constitucional. Votou vencido o Ministro Marco Aurélio que entendia ser possível na espécie o seguimento do recurso por aplicação analógica do artigo 105, II, a da Carta Magna, o qual atribui ao Superior Tribunal de Justiça o julgamento em recurso ordinário de habeas corpus decidido em única instância pelos tribunais dos Estados; e, por fundamento diverso, o Ministro Carlos Velloso por entender que a Constituição Federal consagra como direitos fundamentais aqueles reconhecidos em tratados de que o Brasil seja signatário, por expressa disposição do artigo $5^{\circ}$, parágrafo $2^{\circ}$, da Carta Política de 1988. Precedentes citados: ADInMC 1.480/DF (J. 04.09.1997) e HC 72131/R (j. 22.11.1995). E, mais recentemente, no Agravo Regimental no Agravo de Instrumento 513044/SP, em que foi Relator o Ministro Carlos Velloso, $2^{\text {a }}$ Turma, DJ 08.04.2005, p. 31, a decisão também foi no sentido de que: "Não há no ordenamento jurídico constitucional brasileiro, a garantia constitucional do duplo grau de jurisdição. Prevalência da Constituição Federal em relação aos tratados e convenções internacionais”. Todavia, a hipótese aqui sustentada diz respeito à garantia ao duplo grau de jurisdição no caso de sentenças penais condenatórias em primeiro grau de jurisdição, contemplada no ordenamento jurídico pátrio. Neste sentido, ver POZZEBON, Fabrício Dreyer de Ávila. Breves considerações sobre o direito ao recurso no processo penal brasileiro. Política criminal contemporânea: criminologia, direito penal e direito processual penal. Livraria do Advogado, p. 285-303, 2008.

${ }^{51}$ Inocêncio Borges da ROSA elenca os seguintes fins à sanabilidade dos recursos: a) defeitos graves ou substanciais das decisões; b) a injustiça da decisão; c) a má apreciação da prova; d) a errônea interpretação das pretensões das partes; e) a erônea apreciação dos fatos e das circunstâncias. ROSA. Inocêncio Borges da. Comentários ao Código de Processo Penal. São Paulo: Revista dos Tribunais, 1982. p. 475.

${ }_{52}$ Ao tratar da matéria, Fernando da Costa TOURINHO FILHO (Processo Penal. Op. cit., p. 263), equipara a inconformidade humana a um primeiro julgamento com a necessidade de qualquer pessoa procurar outro parecer médico quando se depara com um diagnóstico mais ou menos grave, mas que lhe é desfavorável. 
Nesse rumo, Afrânio Silva JARDIM ${ }^{53}$ refere que o duplo grau vai ao encontro da própria natureza humana, "pois a parte raramente se satisfaz ou se conforma com uma única decisão jurisdicional, mormente diante da reconhecida falibilidade humana”. Fernando da Costa TOURINHO FILHO, ${ }^{54}$ por sua vez, refere-se à necessidade psicológica do recurso que corresponde e satisfaz a uma tendência irresistível da natureza humana; é a expressão legal do instituto que leva todo o homem a não se sujeitar, sem reação, ao conceito ou sentença do primeiro censor ou Juiz. ${ }^{55}$ Nos ensinamentos de ambos os autores é possível vislumbrar-se a idéia de insubordinação pela apreciação da contenda por apenas um julgador que, sendo humano, pode falhar ao apreender as circunstâncias peculiares do caso posto em julgamento. Desta forma, em que pese a importância do reexame do decisum se dar por uma outra instância como assegura o duplo grau, o enfoque principal aqui sustentado não está na diferença de instâncias, mas sim, no compartilhamento da decisão de modo a conferir maior eficácia material à motivação. Ainda que o ordenamento jurídico, tanto em nível constitucional como infraconstitucional, tenha previsto hipóteses em que este compartilhamento ocorra através da competência originária de órgãos colegiados ou da interposição de recurso.

O reexame dos veredictos, em um primeiro momento, atende à natural inconformidade do ser humano e à necessidade de rever a decisão que lhe é contrária. No entanto, a sua previsão no ordenamento processual exige também ao juiz prolator que fundamente a decisão com maior dedicação e esmero, eis que psicologicamente compelido a julgar com mais cuidado quando cônscio que seu pronunciamento será passível de revisão por outro órgão jurisdicional. Nesta linha, pontifica José Frederico MARQUES ${ }^{56}$ que o duplo grau de jurisdição "constitui fator de grande segurança na aplicação da lei, apresentando, no demais, ação catalítica no aperfeiçoamento das decisões por obrigar o juiz de primeiro grau a maior cuidado e exação na sua tarefa julgadora”.

Além das vantagens já examinadas - a de responder a uma necessidade humana e de consistir em mecanismo de melhor distribuição da justiça -, a reapreciação da decisão terminativa importa também no controle da legalidade e da justiça da sentença, reforçando seu caráter democrático, eis que nenhum ato estatal pode estar alijado de seu acompanhamento pela sociedade ${ }^{57}$. Quanto mais se examinar uma

53 JARDIM, Afrânio Silva. Direito Processual Penal. 11. ed., Rio de Janeiro: Forense, 2003, p. 315.

54 TOURINHO FILHO, Fernando da Costa. Código de Processo Penal Comentado. V. 2. ed. rev., modificada e amp. São Paulo: Saraiva, 1999, p. 260.

${ }^{55}$ ARANHA, Adalberto José Q. T. de Camargo. Dos recursos no Processo Penal. São Paulo: Saraiva, 1988, p. 6. No mesmo sentido o autor aborda a necessidade de dar-se novo exame às decisões terminativas de mérito, fundamentando seu posicionamento em três fatores: a) no jurídico-filosófico, que consiste no dever do Estado de distribuir e realizar a justiça com a menor possibilidade de erro ou dolo, ainda que não se possa falar em acerto total; b) no psicológico, no sentido de que o homem sempre teve espírito de luta, de não-conformação e de defesa; e $c$ ) no histórico, porque entre todos os povos e em todas as épocas, os recursos eram admitidos, ainda que de maneira rudimentar ou mais evoluída, porém em consonância com o grau de civilização de cada povo.

${ }^{56}$ MARQUES, José Frederico. Elementos de Direito Processual Penal. V. I. São Paulo: Forense, 1966, p. 182.

${ }^{57}$ Neste aspecto é que reside o fundamento político do duplo grau de jurisdição, pois como afirmam Ada Pelegrini GRINOVER, Antonio Scarance Fernandes e Antonio Magalhães GOMES FILHO, a revisão das decisões judiciais, configuradoras de atos de poder estatal impositiva às partes e com eficácia natural 
decisão, mais possível será a repartição da justiça. Como bem adverte Enrico ALLORIO apesar das objeções que podem ser levantadas contra o princípio, especialmente porque nada assegura que uma segunda decisão seja positivamente mais correta, não se pode duvidar que o duplo grau de jurisdição aumenta a efetiva chance de uma sentença mais justa. ${ }^{58}$ E aduz Alcides de Mendonça LIMA ${ }^{59}$ com o amplo debate da ação e o exame da decisão em grau superior, como órgãos colegiados, formados de juízes mais experimentados e, presuntivamente, mais cultos, a probabilidade de ser implantada a injustiça é muito menor.

A reapreciação do ato decisório vem implícita no chamado princípio do duplo grau de jurisdição, ${ }^{60}$ que é apresentado pelos doutrinadores pátrios como interligado, de um modo geral, ao estudo dos recursos. Todavia, entende-se imprescindível um novo enfoque à vinculação desses institutos. O que deve ser buscado, principalmente, é o compartilhamento decisório, o que significa a possibilidade de um outro olhar e de outra motivação sobre a causa. No caso aqui tratado, de sentenças penais condenatórias em primeira instância, o duplo grau acaba se impondo como forma de sua implementação. Como afirma CARNELUTTI, ${ }^{61}$ “o colegiado judiciário é verdadeiramente um remédio contra a insuficiência do juiz, no sentido de que, se não a elimina, ao menos a reduz”. Ou seja, “o juiz colegiado está menos longe do que o juiz singular daquilo que o juiz deveria ser”. Na mesma linha, Rogério Schietti Machado CRUZ esclarece que no processo e julgamento dos recursos criminais, o juiz deixa de ser, como é a regra na primeira instância, um julgador monocrático, passando a compor um órgão colegial. "Deve conscientizar-se, portanto, que essa nova feição coletiva traduzirá não mais o pensamento e a vontade dele, senão de vários juízes”. ${ }^{6}$

relativamente a terceiros, é postulado do Estado de Direito, envolvendo controle interno da legalidade e justiça das decisões, por parte de órgão jurisdicional diverso daquele que julgou em primeira instância. No mesmo sentido, Rogério Schietti Machado CRUZ afirma que o direito ao duplo grau decorre,a cima de tudo, do regime democrático,o qual não convive com a possibilidade de que as decisões judiciárias, mormente no terreno penal, sejam irrecorríveis, de forma que por ser a República federativa do Brasil um Estado Democrático de Direito na forma do artigo $1^{\circ}$, caput, da Magna Carta, o princípio do duplo grau de jurisdição encontra guarida em noss ordenamento constitucional. GRINOVER, Ada Pelegrini; FERNANDES, Antonio Scarance; GOMES FILHO, Antonio Magalhães. Recursos no Processo Penal: teoria geral dos recursos, recursos em espécie, ações de impugnação. 2. ed. rev. e atual. São Paulo: Revista dos Tribunais, 1997. p. 22.

${ }^{58}$ ALLORIO, Enrico. Sul doppio grado del processo civile. In: Studi in onore di Enrico Tullio Liebman. V. III. Milano: Giufrée, 1979. p. 1789.

${ }^{59}$ LIMA, Alcides de Mendonça. Introdução aos recursos cíveis. 2. ed. São Paulo: Revista dos Tribunais, 1976. p. 133.

${ }^{60}$ Na esteira de SARLET, Ingo W. (Valor de alçada e limitação ao acesso ao duplo grau de jurisdição: problematização em nível constitucional. Op. cit., p. 126), entende-se que, conquanto a Constituição de 1988 não tenha previsto de maneira expressa a garantia do acesso ao duplo grau de jurisdição, revela-se viável a utilização da alternativa oferecida pelo artigo $5^{\circ}$, parágrafo $2^{\circ}$, da Lei Maior, em se considerando o direito de "recorrer da sentença para Juiz ou tribunal superior tal como previsto no artigo 8*, alínea h, da Convenção Americana sobre Direitos Humanos, como autêntico direito fundamental no sentido material. Ademais, a simples previsão constitucional de instâncias recursais não autoriza a conclusão de que nossa Carta garante de forma absoluta o duplo grau, sob pena de incluir, via hermenêutica, a garantia ao recurso contra qualquer decisão judicial, no âmbito de proteção normativa dos incisos XXXV, LIV e LV, do referido artigo $5^{\circ}$. ${ }^{61}$ CARNELUTTI, Francesco. As misérias do processo penal. São Paulo: Conan, 1995. p. 34.

${ }^{62}$ Sem desconsiderar nesta tese as disfunções dos julgamentos colegiados, adota-se como base o modelo exigível de julgadores que, mesmo com o extraordinário acúmulo de serviço a que são submetidos, estão 
Muito embora a revisão da sentença seja quase sempre submetida à apreciação por um juízo de segundo grau, constituído em geral por magistrados de maior experiência e cultura, leciona Ada Pellegrini GRINOVER ${ }^{63}$ que a distinção entre jurisdição inferior e jurisdição superior não se exaure na relação de subordinação ou hierarquia entre juízes. No mesmo sentido, entende Nelson NERY JÚNIOR: ${ }^{64}$

Mas qual vem a ser o alcance dessa locução “duplo grau de jurisdição”? O que, exatamente, significa? Consiste em estabelecer a possibilidade de a sentença definitiva ser reapreciada por órgão de jurisdição, normalmente de hierarquia superior à daquele que a proferiu, o que se faz de ordinário pela interposição de recurso. Não é necessário que o segundo julgamento seja conferido a órgão diverso ou de categoria hierárquica superior ao daquele que realizou o primeiro exame.

Alude, ainda, Fernando da Costa TOURINHO FILHO ${ }^{65}$ que, embora seja a regra a dualidade de jurisdições, esta não pode ser suposta necessariamente, porquanto em alguns casos o reexame é dirigido ao próprio órgão que prolatou a decisão combatida. Assim, pela doutrina referida, é autorizado concluir que a garantia do reexame das decisões judiciais, e mesmo a do duplo grau (expressamente prevista na Convenção Americana sobre Direitos Humanos ${ }^{66}$ - norma de Direito Internacional

ciosos da relevância das funções que exercem em um Estado Democrático de Direito. Como exemplo dessas disfunções, aponta STRECK, Lênio Luiz (Tribunal do júri: símbolos \& rituais. 3. ed. Porto Alegre: Livraria do Advogado, 1998. p. 51):“grande parte das sentenças, pareceres, petições e acórdãos são resolvidos através de citações do tipo 'nessa linha a jurispurdência é pacífica', ignorando o contexto histórico e social no qual estão inseridos os atores jurídicos (acusado, vítima, juiz, promotor , advogado) e a circunstância em que emergiu a ementa jurispurdencial utilizada. Na mesma linha, DALLARI, Dalmo de Abreu (O poder dos juízes. São Paulo: Saraiva, 1996. p. 95) critica a as citações doutrinária eruditas ou com palavras e frases rebuscadas, muitas vezes centardas na discussão de formalidades processuais ou de questões irrelevantes e secundárias, sem dar a devida impoirtância “à questão da justiça das decisões”. E finalmente, CRUZ, Rogério Schietti Machado (Op. cit., p. 63-65), destaca votos de relator nem sempre suficientemente fundamentado, que é seguido pelos demais julgadores de acordo com um simples "de acordo com o relator", o que não traduziria qualquer problema, "não fosse a transmissão amiúde da sensação de que para a deliberação judicial desses casos somente o relator se preparou, redigindo previamente um voto que será lido em sessão, sem qualquer debate entre os julgadores, ou entre estes e as partes, prática que, na essência, transforma esse julgamento, previsto para ser fruto de uma decisão colegiada, em uma virtual, segunda decisão monocrática, com o agravante de ter sido prolatada, por magistrado distante das provas e das partes. Sem contar outro grave tangenciamento do dever de fundamentar que é a denominada motivação “ad relationem”, extraída de outra decisão judicial (do próprio processo ou não), ou pior, do parecer do Ministério Público, e em ambos os casos, sem acréscimos argumentativos do julgador.

${ }^{63}$ GRINOVER, Ada Pellegrini; FERNANDES, Antonio Scarence; GOMES FILHO, Antonio Magalhães. Recursos no Processo Penal: teoria geral dos recursos, recursos em espécie, ações de impugnação. Op. cit., p. 27. ${ }^{64}$ NERY JÚNIOR, Nelson. Princípios fundamentais: teoria geral dos recursos. 5. ed. rev. e ampl. São Paulo: Revista dos Tribunais, 2000. p. 43.

${ }^{65}$ TOURINHO FILHO, Fernando da Costa. Código de Processo Penal Comentado. Op. cit., p. 574.

${ }^{66}$ Segundo o disposto no artigo $8^{\circ}$, n. 2, alínea "h”, do Pacto de San José da Costa Rica, também referido por Ingo Sarlet, "toda pessoa acusada de delito tem direito a que se presuma sua inocência enquanto não se comprove legalmente sua culpa. Durante o processo, toda pessoa tem direito, em plena igualdade, às seguintes garantias mínimas: (...) h) direito de recorrer da sentença para juiz ou tribunal superior”. A Convenção Americana sobre os Direitos do Homem foi celebrada no âmbito da Organização dos Estados Americanos, em San José da Costa Rica, no dia 22 de novembro de 1969, e entrou em vigor 
devidamente transplantada para o regramento pátrio pelo Decreto n. 678, de 6 de novembro de 1992), se justifica pelo julgamento por órgãos, supostamente mais capacitados, mas, principalmente, na idéia de "revisão” ou "reapreciação do veredicto", conferindo maior eficácia material à motivação como direito fundamental. Nesta linha, cumpre colacionar a lição de Ada Pellegrini GRINOVER, ${ }^{67}$ ao tratar da necessidade ou não de uma limitação à matéria recorrida, quando afirma que "para os sistemas, como o nosso, em que o juízo de primeiro grau é monocrático, é preferível estender o duplo grau de jurisdição à matéria de fato, como garantia de uma correta valoração dos fatos”. Em outras palavras, mostra-se necessária a devolução das questões de fato e de direito a um órgão colegiado quando a decisão terminativa for exarada por um juízo penal singular, de forma a agregar outro olhar à causa e conferir maior eficácia material à motivação como direito fundamental. E, efetivamente, é neste sentido que se encontra inserida a garantia do reexame das decisões no ordenamento jurídico pátrio. Um segundo olhar sobre a hipótese delitiva apresenta-se como uma estratégia essencial à distribuição da justiça, na medida em que assegura a diversidade de juízos sobre o evento punível e sobre a culpabilidade do acusado, disparidade esta que decorre da própria natureza humana e da alteridade nela atuante.

\section{CONCLUSÃO}

Pelo exposto, o direito fundamental à motivação, em primeiro e segundo graus de jurisdição, possível diante da abertura material permitida pelo art. $5^{\circ}$, $\S 2^{\circ}$, da CF, encontra justificativa não só na nulidade decorrente da sua inobservância estabelecida pelo legislador constituinte, mas também e com ênfase, na sua íntima relação com outras garantias constitucionais, necessárias ao devido processo penal onde periclita o sagrado jus libertatis, especialmente de modo a emprestar-lhes maior eficácia material, propiciando visibilidade: às partes, aos órgãos judiciais revisores e à própria sociedade.

\section{BIBLIOGRAFIA}

AGAMBEM, Giorgio. Homo Sacer: o poder soberano e a vida nua. Belo Horizonte: UFMG, 2004.

ALLORIO, Enrico. Sul doppio grado del processo civile. In: Studi in onore di Enrico Tullio Liebman. V. III. Milano: Giufrée, 1979.

ARANHA, Adalberto José Q. T. de Camargo. Dos recursos no Processo Penal. São Paulo: Saraiva, 1988.

ARENDT, Hanna, Sobre a Violência. Rio de Janeiro: Relume-Dumará, 1994.

BETTIOL, Giuseppe. Instituciones de Derecho Penal y Procesal. Barcelona: Bosch, 1977.

BOBBIO, Norberto. Teoria do Ordenamento Jurídico. 6. ed. Brasília: UnB, 1982.

BRAGA, Affonso. Instituições de Processo Civil no Brasil. V. 3. Rio de Janeiro: Forense, 1941.

internacional em 18 de julho de 1978. O Governo do Brasil aderiu ao ato internacional somente em 25 de setembro de 1992, ocasião em que a promulgou através do Decreto n 678, datado de 6 de novembro de 1992. ${ }^{67}$ GRINOVER, Ada Pellegrini; FERNANDES, Antonio Scarence; GOMES FILHO, Antonio Magalhães. Recursos no Processo Penal: teoria geral dos recursos, recursos em espécie, ações de impugnação. Op. cit., p. 25-26.

DIREITOS FUNDAMENTAIS E JUSTIÇA N 8 - JUL./SET. 2009 
CAMPILONGO, Celso Fernandes. Política, Sistema Jurídico e Decisão Judicial. São Paulo: Max Limonad, 2002.

CANOTILHO, José Joaquim Gomes. Direito Constitucional. 5. ed. Coimbra: Almedina, 1992, p. 349.

CARNELUTTI, Francesco. As misérias do Processo Penal. São Paulo: Conan, 1995.

CARVALHO, Luis Gustavo Grandinetti Castanho. Processo Penal e Constituição. Princípios Constitucionais do Processo Penal. Rio de Janeiro: Lumen Juris, 2004.

CARVAlHO, Márcia Dometila Lima de. Fundamentação Constitucional do Direito Penal. Porto Alegre: Sérgio Antonio Fabris, 1992.

COSTA, Nelson Nery; ALVES, Geraldo Magela. Constituição Federal anotada e explicada. Rio de Janeiro: Forense, 2002.

COUTURE, Eduardo J. Fundamentos del Derecho Procesal civil. 3. ed. Buenos Aires: DEPALMA, 1972.

CRUZ, Rogério Schietti Machado. Garantias Processuais nos Recursos Criminais. São Paulo: Atlas, 2002.

DALLARI, Dalmo de Abreu. O poder dos Juízes. São Paulo: Saraiva, 1996.

FERNANDES, Antonio Scarance. Processo Penal Constitucional. São Paulo: Revista dos Tribunais, 1999.

FERRAJOLI, Luigi. Direito e razão: teoria do garantismo penal. Tradução de: Ana Paula Zomer, Fauzi Hassan Choukr, Juarez Tavares e Luiz Flávio Gomes. São Paulo: Revista dos Tribunais, 2002.

GIACOMOLLI, Nereu José. Juizados Especiais Criminais: Lei 9.099/95. 2. ed. Porto Alegre: Livraria do Advogado, 2002.

GOMES FILHO, Antônio Magalhães. A Motivação das Decisões Penais. São Paulo: Revista dos Tribunais, 2001. Presunção de inocência prisão cautelar. São Paulo: Saraiva, 1991.

GRINOVER, Ada Pellegrini; FERNANDES, Antonio Scarance; GOMES FILHO, Antonio Magalhães. As nulidades no Processo Penal. 7. ed. rev. e atual. São Paulo: Revista dos Tribunais, 2001. Novas tendências do Direito Processual. Rio de Janeiro: Forense, 1990.

Recursos no Processo Penal: teoria geral dos recursos, recursos em espécie, ações de impugnação. 2. ed. rev. e atual. São Paulo: Revista dos Tribunais, 1997.

JARDIM, Afrânio Silva. Direito Processual Penal. 11. ed. Rio de Janeiro: Forense, 2003.

JIMENEZ, Hernando Londoño. Derecho Procesal Penal. Bogotá: Têmis, 1982.

LIMA, Alcides de Mendonça. Introdução aos Recursos Cíveis. 2. ed. São Paulo: Revista dos Tribunais, 1976.

MARQUES, José Frederico. Elementos de Direito Processual Penal. V. I. São Paulo: Forense, 1966.

MEDEIROS, Flávio Meirelles. Princípios de Direito Procesual Penal. Porto Alegre: Ciências Jurídicas, 1984.

MELLENDO, Santiago Sentís. In dubio pro reo. Buenos Aires: EJEA, 1971.

MORIN, Edgar. Introdução ao Pensamento Complexo. Lisboa: Instituto Piaget, 1991. 
NERY JÚNIOR, Nelson. Princípios fundamentais: teoria geral dos recursos. 5. ed. rev. e ampl. São Paulo: Revista dos Tribunais, 2000.

POZZEBON, Fabrício Dreyer de Ávila. Breves considerações sobre o direito ao recurso no processo penal brasileiro. Política criminal contemporânea: criminologia, Direito Penal e Direito Processual Penal. Livraria do Advogado, p. 285-303, 2008.

PRADO, Geraldo. Sistema acusatório. A conformidade constitucional das leis procesuais penais. 3. ed. Rio de Janeiro: Lumen Juris, 2005.

RANGEL, Paulo. Direito Processual Penal. Rio de Janeiro: Lumen Juris, 2004.

ROSA. Inocêncio Borges da. Comentários ao Código de Processo Penal. São Paulo: Revista dos Tribunais, 1982.

SÁ, Alexandre Franco de. Metamorfose do Poder. Coleção Sophia. Coimbra: Ariadne, 2004.

SARLET, Ingo Wolfgang. Valor de alçada e limitação ao acesso ao duplo grau de jurisdição: problematização em nível constitucional, à luz de um conceito material de direitos fundamentais. Revista da AJURIS, Porto Alegre, v. 66, p. 89, 1996.

A Eficácia dos Direitos Fundamentais. 3. ed. rev., atual. e ampl. Porto Alegre: Livraria do Advogado, 2003.

Dignidade da pessoa humana e direitos fundamentais na Constituição Federal de 1988. 2. ed. rev. ampl. Porto Alegre: Livraria do Advogado, 2002.

SILVA, Tadeu Antônio Dix. Liberdade de expressão e Direito Penal no Estado Democrático de Direito. São Paulo: IBCCrim, 2000.

SMANIO, Giampaolo Poggio. Criminologia e Juizado Especial Criminal. São Paulo: Atlas, 1997.

STRECK, Lênio Luiz. Tribunal do júri: símbolos \& rituais. 3. ed. Porto Alegre: Livraria do Advogado, 1998.

TOURINHO FILHO, Fernando da Costa. Processo Penal. V. 4. São Paulo: Saraiva, 2004. Saraiva, 1999.

Código de Processo Penal Comentado. V. 2. ed. rev., modificada e amp. São Paulo:

TUCCI, Rogério Lauria. Direitos e garantias individuais no Processo Penal Brasileiro. São Paulo: Saraiva, 1993. 1989. e TUCCI, José Rogério Cruz e. Constituição de 1988 e Processo. São Paulo: Saraiva,

VASCONCELOS, Maria Lúcia Marcondes Carvalho (Org.). Educação e história da cultura: fronteiras. São Paulo: Mackenzie, 2002.

WEINGARTNER NETO, Jayme. Honra, privacidade e liberdade de imprensa - uma pauta de justificação penal. Porto Alegre: Livraria do Advogado, 2002. 